\title{
Verdadeiro Deus e verdadeiro homem: um estudo sobre a cristologia de Santo Inácio de Antioquia
}

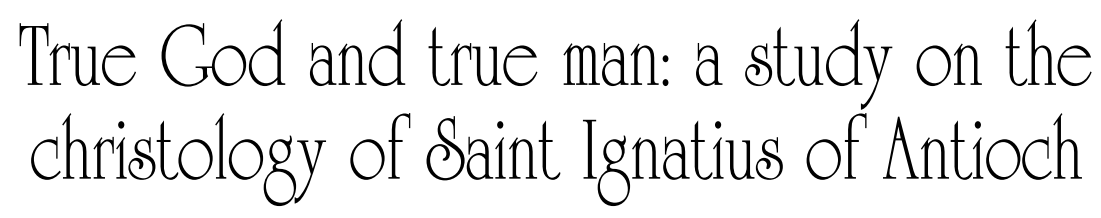

Renato da Silva Machado*

Resumo: Com a Evangelii Gaudium a Igreja procura propor a fé para o mundo de hoje, como possibilidade verdadeira de encontro de um sentido para a vida. A fé é um dom de Deus, que nos é oferecido, para que através do Espírito, possamos nos abrir à revelação do Deus Trino em Jesus Cristo, Caminho, Verdade e Vida. Para que cheguemos a essa fé, necessitamos da pregação, pois o Apóstolo Paulo diz: "a fé vem da pregação”, e em nossa época é preciso que essa pregação seja feita com convicção de modo a propiciar a adesão a Jesus Cristo.

Palavras-chave: Igreja; Pregação; Sentido da Vida; Jesus Cristo.

Abstract: With Evangelii Gaudium the Church seeks to propose the faith to the world today, as real possibility of a meaning for life. Faith is a gift of God offered to us, so that through the Spirit, we open ourselves to the revelation of the Triune God in Jesus Christ, Way, Truth and Life. For we come to this faith, we need the preaching, because the Apostle Paul says, "Faith comes from preaching," and in our time it is necessary that this preaching is done with conviction in order to provide adherence to Jesus Christ.

Keywords: Church; Preaching; Meaning for Life; Jesus Christ.

* Mestre em Teologia pela Pontifícia Universidade Católica do Rio de Janeiro e doutorando em Teologia na PUC-RJ e na Pontificia Facoltà dell’Italia Meridionale. E-mail: remadc@ hotmail.com. 


\section{Introdução}

Há pouco tempo, a Igreja se reuniu em Sínodo para refletir sobre a Nova Evangelização, propondo caminhos para alcançá-la, o que propiciou a redação do Documento Evangelii Gaudium. Não se trata de, como no passado, impor a fé cristã, mas propor esta fé como possibilidade de encontrar o sentido para a vida. A fé é dom de Deus, que, por meio do seu Espírito, nos abre à revelação do Deus Trino em Jesus Cristo. No entanto, esta mesma fé necessita da pregação para que seja suscitada, pois como afirma Paulo: "a fé vem da pregação" (Rm 10,17). Em nossos tempos, é preciso que a pregação seja realizada com convicção de modo a propiciar a adesão a Cristo Jesus. Não se deve pretender apenas aumentar o número de cristãos pela força da argumentação, pois "a Igreja não cresce por proselitismo, mas por atração". Antes, ela precisa ser um instrumento eficaz no mundo para que, em meio a tantas vozes, se faça sentir bem alto a voz de Cristo, que convida a segui-Lo. Somos chamados, assim, a aprofundar e proclamar esta fé com maior ardor, a fim de que sua beleza possa ser percebida e tantos outros venham a se sentir atraídos por ela. No mundo hodierno, no qual a verdade é relativizada, se faz necessário o anúncio, vale dizer, apresentar a proposta cristã como encontro de sentido para a existência.

Esta missão de fazer o Cristo ser conhecido e amado não é somente de uma parcela da Igreja. Cada batizado recebeu diretamente do Cristo a missão de evangelizar: "Ide e fazei discípulos meus todos os povos, batizando-os em nome do Pai, do Filho e do Espírito Santo e ensinando-os a observar tudo o que vos mandei" (Mt 28,19). No último Sínodo, sobre a Evangelização, Bento XVI lembrou na homilia de conclusão:

A Igreja tem o dever de evangelizar, de anunciar a mensagem da salvação aos homens que ainda não conhecem Jesus Cristo (...). Por isso, é preciso pedir ao Espírito Santo que suscite na Igreja um re-

1 BENTO XVI. Homilia da missa inaugural da V Conferência Latino-Americana em Aparecida, a 13 de maio de 2007. In Documento de Aparecida-Texto Conclusivo da V Conferência Geral do Episcopado Latino-Americano e do Caribe. n. 159. 
novado dinamismo missionário, cujos protagonistas sejam, de modo especial, os agentes pastorais e os fiéis leigos. (...) Todos os homens têm o direito de conhecer Jesus Cristo e o seu Evangelho; e a isso corresponde o dever dos cristãos - de todos os cristãos: sacerdotes, religiosos e leigos - de anunciarem a Boa Nova. ${ }^{2}$

Cada batizado é chamado a fazer com que a fé em Cristo seja difundida em toda parte. Cada qual é convocado a professar, com a vida e com a boca, a Salvação que Cristo pode proporcionar, a oferecer aos homens e às mulheres de hoje as razões de nossa esperança (cf. 1Pd 3,15). Daí a importância de aprofundar a fé cristã, a fim de que ela possa ser profundamente vivenciada e testemunhada; crescer na fé que é, antes de tudo, cristológica, pois implica acreditar em uma pessoa, Jesus Cristo, descobrindo-o como Senhor e Salvador, e reconfigurar a vida a partir de suas palavras, de seu exemplo e de sua graça.

Contudo, percebem-se, em nossos dias, alguns reducionismos vividos na espiritualidade e na práxis dos cristãos que impedem que o anúncio da pessoa de Jesus Cristo possa ser feito de modo integral. Estes reducionismos têm como pressuposto uma cristologia que não integra o Cristo da fé com o Jesus da história, a verdadeira divindade de Jesus com a verdadeira humanidade de Cristo, o crucificado com o ressuscitado, conforme se herdou da tradição eclesial. Em alguns meios (espiritualistas) existe a hipervalorização da divindade de Jesus em detrimento de sua humanidade. A humanidade, a condição histórica de Jesus é esquecida, quando não é negada. Na vida de Jesus, é enfatizada apenas a questão das curas e milagres, distanciando-se, na maioria das vezes, da intenção mesma dos evangelhos ao trazer presentes tais relatos. Por outro lado, em outros ambientes (racionalistas), percebe-se a valorização da humanidade de Jesus, dos seus gestos, palavras e atitudes, desconsiderando sua divindade. Para muitos, Jesus é apenas um homem que viveu de forma coerente com sua pregação, uma pessoa verdadeiramente ética, um profeta, e, assim, não chegam a reconhecer ou, até mesmo, negam sua divindade.

2 BENTO XVI. Homilia da conclusão do Sínodo sobre a Nova Evangelização em Roma, a 28 de outubro de 2012. Cf. http://www.vatican.va/holy_father/benedict_xvi/homilies/2012/ documents/hf_ben-xvi_hom_20121028_conclusione-sinodo_po.html. 
No intuito de colaborar para a apresentação da genuína fé cristã na unidade entre divindade e humanidade de Jesus, pretende-se, nestas poucas páginas, apresentar a cristologia de Santo Inácio de Antioquia, valente defensor da fé cristã. Ele apresenta a realidade da divindade e humanidade em Jesus Cristo, sem dividi-las ou separá-las; ao contrário, mostra que somente a perfeita articulação entre ambas torna possível a nossa salvação.

\section{Inácio de Antioquia: vida e obras ${ }^{3}$}

Santo Inácio de Antioquia situa-se entre aqueles escritores que, por terem sucedido imediatamente aos Apóstolos, são chamados de Padres Apostólicos. Inácio foi, depois do Apóstolo Pedro, o terceiro bispo da cidade de Antioquia. No reinado de Trajano (98 - 117 d.C.) foi preso e transferido para Roma e martirizado, sendo lançado às feras por volta do ano de 110. O martírio, para Inácio, significava manifestar o verdadeiro discipulado de Cristo, seguindo a este em sua paixão e em sua cruz. Por isso, sabendo que os cristãos romanos poderiam tentar impedir o seu martírio, pede-lhes que não o façam. ${ }^{4}$ Segundo ele, um discurso que não se concretizasse em martírio seria um discurso mentiroso; apenas palavras, sem merecimento de fé. Não se trata, no caso, de um "sadomasoquista", de alguém que encontra prazer no sofrimento em si mesmo, mas da mística de um bispo que tem a intenção de pôr a sua própria vida em sintonia com a fé que professa e percebe que seu derramamento de sangue seria um testemunho, um encorajamento na fé para muitos.

Ao longo da viagem a caminho do martírio, da Síria a Roma, capital do Império, escreve sete cartas endereçadas àqueles com os quais manteve alguma relação fraterna: as comunidades cristãs de Éfeso, Magnesia, Trali, Filadelfia, Esmirni, Roma e o bispo Policarpo de Esmirni. Elas foram escritas, lidas e reunidas com muita veneração

\footnotetext{
3 Prefere-se aqui não apresentar pormenores da vida de Inácio, mas apenas os dados necessários à posterior reflexão sobre sua cristologia.

4 Cf. LAPORTE, J. I Padri della Chiesa, p. 276.
} 
na Ásia Menor. ${ }^{5}$ Não são tratados teológicos, mas, antes, testemunhos de um crente, prestes a morrer, que tem o desejo ardente de frisar o essencial da fé em meio à situação concreta em que viviam as comunidades cristãs no final do século I. ${ }^{6}$ Tratam basicamente da vida cristã, da eucaristia, das estruturas das comunidades, da unidade e do martírio em perspectiva da fé.

Segundo Inácio, a vida e tudo o que diz respeito à fé têm a sua centralidade no mistério de Cristo. Os cristãos são membros de Cristo, pedras vivas do Templo de Deus, aqueles que buscam seguir os seus mandamentos ou, ainda, aqueles que, embora em carne, vivem segundo o espírito. ${ }^{7}$ Mas os cristãos são, sobretudo, crentes em Jesus Cristo. ${ }^{8}$ A fé em Jesus Cristo é aquilo que move a comunidade cristã e cada um de seus membros, fazendo-os viver na caridade. ${ }^{9}$ De nada vale qualquer conhecimento a respeito dos seres celestes se não se crê no sangue de Cristo. ${ }^{10}$ É por meio deste sangue que obtemos a salvação, é por meio dele que somos santificados no batismo, participando da salvação de Cristo, que nasceu e foi batizado para purificar a água com a sua paixão. ${ }^{11}$

\section{A cristologia presente nas cartas de Inácio de Antioquia}

\section{Jesus é Deus e homem verdadeiramente}

Nas cartas de Inácio de Antioquia percebe-se a grande aproximação entre os textos patrísticos e os textos neotestamentários, em

5 Cf. SMUlDERS, P. Sínteses do Catolicismo primitivo I: A Palavra de Deus na história humana: Inácio, Justino, Irineu In FEINER, J.; LÖHRER, M. (ed.), Mysterium Salutis, III/3, p.15.

6 ARNS, P. E. Cartas de Inácio de Antioquia, p. 14.

7 Efe IV 2; IX 1-2; VIII 2. Neste trabalho as citações bíblicas estão no corpo do texto enquanto as citações referentes às cartas de Inácio, nas notas de rodapé. Estes e demais textos de Inácio são extraídos de ARNS, P. E. Cartas de Inácio de Antioquia.

8 Efe I.

9 Efe I; XII 1.

${ }^{10}$ Esm, IV.

11 Esm XVIII 2. 
especial os de João e Paulo. ${ }^{12}$ Nota-se o uso das mesmas expressões, a repetição de temas tratados no corpo joanino e paulino, como também o modelo de cristologia descendente ou "do Alto", comum no ambiente antioqueno. ${ }^{13}$ Observa-se, ainda, certa evolução na elaboração teológica ao utilizar termos caros a João e Paulo, como a expressão "Deus" quando quer se referir a Jesus. ${ }^{14}$ Inácio chama naturalmente Jesus de "Deus":

Inácio, também chamado Teóforo, à Igreja que recebeu misericórdia pela grandeza do Pai altíssimo e de Jesus Cristo Seu Filho único, Igreja amada e iluminada pela vontade d'Aquele que escolheu todos os seres, isto é, segundo a fé e a caridade de Jesus Cristo nosso Deus (...) desejo todo o bem e irrepreensível alegria em Cristo Jesus nosso Deus. ${ }^{15}$

Inácio afirma que Jesus é o Filho, que se achava junto do Pai desde a eternidade e que se manifestou no fim dos tempos. Com isto, evidencia categoricamente a divindade de Jesus, apresentando a preexistência de Cristo antes da criação do mundo e situando-o na condição eterna de Deus; e, neste sentido, o próprio existir do mundo, que está relacionado a Cristo e surge como fruto de sua vontade. ${ }^{16}$ Desta forma, já se pode perceber na teologia de Inácio a mediação

\footnotetext{
12 Bueno apresenta esta aproximação de Inácio com João através de três elementos. 0 primeiro é o vocabulário comum (amor, vida, luz, verdade, carne, espírito, alegria, paz, união, mundo, pão, sangue, água, dentre outras...). O segundo é a cristologia de descida. Ambos partem da clara confissão da divindade de Jesus, da convicção do Verbo, do preexistente, por quem Deus se manifesta no mundo, palavra que procede do silêncio. 0 terceiro se refere aos adversários comuns a João e a Inácio - os docetas. Já em relação à aproximação com Paulo, ele apresenta, entre outros, os temas comuns vida e esperança, atribuídos a Cristo. Cf. BUENO, D. R. Padres apostólicos, pp. 384-399.

${ }^{13}$ A cristologia do Alto desenvolvida em Antioquia tem sua motivação no conflito com os judeus, diferentemente do que ocorre em Roma, onde se percebe uma comunidade de influência judaizante que desenvolve uma cristologia de baixo. Cf. COSTA, P. C. Trindade e cristologia no contexto teológico do II século In Teocomunicação, pp. 817-818.

${ }^{14}$ Cf. LIÉBAERT, J. Padres da Igreja, p. 25.

${ }^{15}$ Rom Introdução.

${ }^{16}$ Cf. Mag 6,1; 8,2; Rom. Introdução; Efe Introdução; Efe 15; Mag 6,1; 8,2. Em relação à paternidade de Deus, enquanto para Clemente de Roma se refere primeiramente à criação, em Inácio se refere ao Filho. Cf. COSTA, P. C. Trindade e cristologia no contexto teológico do II século In Teocomunicação, p. 818.
} 
de Cristo na criação e, ainda, a relação de Cristo com a economia veterotestamentária. ${ }^{17}$

Além disso, Inácio mostra a unidade indissolúvel do Pai ao afirmar que Jesus Cristo "saiu de um só Pai, permaneceu num só e a Ele voltou". ${ }^{18}$ Ele "nada fez sem o Pai, com o qual estava unido, nem pessoalmente, nem através dos apóstolos”. ${ }^{19}$ Esta unidade mostra-se evidente na expressão com a qual Inácio se refere a Jesus, o "Amado”, 20 já usada na Sagrada Escritura (cf. Mt 3,17; 12,18; Ef 1,6) e que, mais tarde, Agostinho também adotará ao tratar da Trindade. ${ }^{21}$

Anunciando a divindade de Jesus, Inácio sustenta que Jesus é o "Verbo proveniente do Silêncio". ${ }^{22}$ Isto implica afirmar a condição divina de Jesus e, ao mesmo tempo, mostrar que, com a encarnação do Filho, o silêncio de Deus foi "quebrado”, Deus se autocomunicou ao ser humano. ${ }^{23}$ Em Jesus, Deus pode ser conhecido e amado: "Quem me viu, viu o Pai” (Jo 14,9). O Verbo encarnado é a expressão do ser de Deus (cf. Hb 1,3), o lugar no qual Deus se tornou acessível ao ser humano, permitindo-se ser acolhido no amor assim como o Filho é o amado do Pai (cf. Mt 3,17). Nele, o ser humano encontra a possibilidade de se relacionar com o Deus vivo em uma condição filial e amorosa.

Jesus, a Palavra manifesta do Pai, nos revela o Pai sem, no entanto, exaurir o seu Mistério. Neste sentido, Forte, baseado no pensamento de Inácio, sustenta que "para além da Palavra encarnada continua existindo o silêncio do Verbo, a transcendência do Filho eterno, inacessível à captação do conhecimento humano”. ${ }^{24} \mathrm{O}$ Verbo encarnado de forma alguma aprisiona Deus, que continua sendo Mistério, bem longe de qualquer compreensão humana. Desta forma, conclui-se que afirmar a encarnação do Verbo, a autocomunicação de Deus em Jesus de Nazaré, significa percebê-lo como evento que nos faz ir para além do manifesto, e nos direciona para aquele que permanece Silêncio.

${ }^{17}$ Cf. Filad. 9.

${ }^{18}$ Cf. Mag 7,2.

${ }_{19}$ Mag 7,1.

${ }^{20}$ Cf. Esm Introdução.

${ }^{21}$ AGOSTINHO. Trindade. VIII 10,14.

${ }^{22}$ Cf. Mag 8,2.

${ }^{23}$ DELL'OSSO, C. I Padri apostolici. Traduzione, introduzione e note, p. 97.

${ }^{24}$ FORTE, B. Teologia da história: ensaio sobre a revelação, o início e a consumação, p.108. 
Neste sentido, assevera Inácio: "Quem possui realmente a palavra de Jesus também percebe o seu silêncio, para que seja perfeito, para que opere através das coisas de que fala e seja reconhecido por meio daquelas coisas sobre as quais se cala”. ${ }^{25}$ Jesus, Palavra feita carne, é aquele que nos remete ao Silêncio da origem, é o Deus visível que nos remete ao Deus invisível (cf. Cl 1,15; 2Cor 4,4; Hb 1,3) e que nos ensina a viver em comunhão com ele. Escutar a Palavra de Cristo é ir para além desta Palavra, é direcionar-se à profundidade do Mistério para o qual esta Palavra aponta.

Se, por um lado, se nota o ensinamento de Inácio em relação à divindade de Jesus, por outro, com a teologia do Verbo, se observa o ensinamento acerca da realidade da encarnação, enfatizada com o termo "de fato" (= verdadeiramente), que se constitui num dos dois argumentos fundamentais contidos nas suas cartas. ${ }^{26}$ Por diversas vezes ele insiste nesta expressão para sublinhar a realidade da encarnação:

Mantende-vos surdos na hora em que alguém vos falar de outra coisa que de Jesus, da descendência de Davi, filho de Maria, o qual nasceu de fato, comeu e bebeu, foi de fato perseguido sob Pôncio Pilatos, de fato foi crucificado e morreu à vista dos que estão nos céus, na terra e debaixo da terra. 0 qual de fato também ressurgiu dos mortos, ressuscitando-0 o próprio Pai. ${ }^{27}$

Em Inácio, percebe-se a insistência da veracidade, seja da divindade, seja da humanidade de Jesus. Se, por um lado, afirma a divindade de Jesus, por outro, mostra a real humanização do Filho de Deus:

Um é o médico,

em carne

e em espírito,

gerado

aparecendo na carne

e não gerado,

na morte

como Deus,

tanto de Maria vida verdadeira

como de Deus,

\footnotetext{
${ }^{25}$ Efe 15,1-2.

${ }^{26}$ Segundo Simonetti, a realidade da encarnação de Cristo e a obediência devida ao bispo são os dois temas fundamentais do conjunto das cartas de Inácio. Cf. SIMONETTI, M. Letteratura Cristiana antica. Antologia di testi. Vol. I Dalle origini al terzo secolo.

${ }^{27}$ Tra 9,1.
} 
primeiro capaz de sofrer, Jesus Cristo Senhor Nosso. ${ }^{28}$

depois impassível,

Santo Inácio apresenta Jesus Cristo como homem e Deus. Um e mesmo. Neste sentido é que afirma que é de Maria como é de Deus; "que descende segundo a carne de Davi, filho do homem e filho de Deus" ${ }^{29}$ Este trecho mostra de modo claro, a divindade e humanidade presentes em Jesus Cristo. Em outro texto sustenta ainda: "pois nosso Deus, Jesus Cristo, tomou carne no seio de Maria segundo o plano de Deus, sendo um descendente de Davi, provindo por outro do Espírito Santo" ${ }^{30}$ Apresenta-se, deste modo, na mesma realidade, que Jesus Cristo é a unidade do humano com o divino, que, séculos mais tarde, no Concílio de Calcedônia, teria sua formulação definitiva acerca das duas naturezas na única pessoa do Filho. ${ }^{31}$

\section{A questão do docetismo e gnosticismo}

A ênfase dada à veracidade da divindade e da humanidade em Jesus Cristo tem a sua razão de ser. Dá-se por conta de dois problemas identificados por Inácio: o ebionismo ou judeu-cristianismo heterodoxo, que negava a divindade de Jesus, e o docetismo ou gnosticismo heterodoxo, que limitava-se a perceber somente uma humanidade aparente em Cristo. ${ }^{32}$

A comunidade eclesial, em todos os momentos históricos, é chamada a expressar sua fé nas diferentes culturas e contextos para que o Evangelho seja, de fato, acolhido nos corações dos homens e das culturas. Não foi diferente no início do Cristianismo. Já nas origens, a comunidade cristã necessitou dialogar com a cultura judaica e com a cultura grega.

\footnotetext{
${ }^{28}$ Efe $7,2$.

${ }^{29}$ Efe 20,2.

${ }^{30}$ Efe 18,2.

31 Cf. CARDENAL, O. G. Cristologia, p. 199.

${ }^{32}$ Sobre o que segue em relação ao judeu-cristianismo e ao gnosticismo, ver SESBOÜÉ, B. História dos Dogmas. O Deus da Salvação. Tomo 1, pp. 29-66.
} 
Do diálogo com a cultura judaica, resultou o que se pode chamar de judeu-cristianismo. Trata-se de uma forma de expressão da fé em Jesus Cristo que segue o modo de pensar do Judaísmo, ou seja, a interpretação da fé a partir de uma estrutura semítica, que foi útil e necessária para exprimi-la naquele contexto. Dentre os que se encorajaram nesta tendência está Inácio de Antioquia. Nota-se que Inácio se pauta na estrutura do judeu-cristianismo quando, por exemplo, faz uso da expressão semítica "Nome" de Deus. No Antigo Testamento, "Nome” é utilizado muitas vezes no lugar do tetragrama YHWH, significando, ao mesmo tempo, revelação e escondimento. É utilizado no Novo Testamento para se referir também a Jesus (cf. Rm 10,12-13; Jo 17,6), na tendência da apropriação do judeu-cristianismo. Inácio se apropria do termo "Nome” para designar a Cristo:

Assim ouvindo que eu vinha da Síria, preso pelo Nome e pela esperança que nos são tão comuns, confiando chegar até Roma para combater as feras, graças à vossa oração, a fim de ter a felicidade de tornar-me discípulo, vós vos apressastes em ver-me. ${ }^{33}$

Desta forma, se utiliza da compreensão judaica para exprimir a novidade da fé cristã de modo a ser inteligível pelos judeus.

A “teologia judaico-cristã” é uma teologia da glória. ${ }^{34}$ Mesmo a cruz rapidamente se tornou um símbolo de glória, instrumento de salvação. A cruz é tomada no sentido de exaltação, de vitória, de uma realidade que abre caminho a outra dimensão. Mergulhado nesta compreensão é que Inácio chama a cruz de mastro, alavanca. ${ }^{35} \mathrm{~A}$ reflexão judaico-cristã, no entanto, é uma vertente heterodoxa da fé cristã. A principal questão relacionada à heterodoxia se refere à recusa da divindade de Cristo. Os que negavam a divindade de Cristo eram chamados de "ebionitas", ou seja, tinham uma cristologia "pobre". Sua cristologia via, na pessoa de Jesus, apenas o maior dos profetas

\footnotetext{
${ }^{33}$ Efe 1,2. E, ainda, em Efe 3,1: "Mesmo que carregue os grilhões pelo Nome, ainda não cheguei à perfeição em Jesus Cristo."

${ }^{34}$ Cf Daniélou, J. Théologie Du Judéo-Christianisme In SESBOÜÉ, B; WOLINSKI, J. História dos Dogmas. O Deus da Salvação, p. 35.

${ }^{35}$ Efe 9,1 .
} 
e não, o Filho de Deus. Tratava-se do esforço de manter, em sentido estrito, o monoteísmo judaico, não aceitando outras pessoas em Deus.

Entretanto, o desenvolvimento do Cristianismo ocorreu, não só dentro do universo judaico, como também dentro do mundo grego e, de forma especial, o gnosticismo, movimento histórico, latente nos séculos II e III, que salvação pelo conhecimento. Esta tendência possuía uma atitude anticósmica e anticarnal que levava a uma visão de que o mundo visível era mau. A cristologia, neste sistema, desenvolveu-se “doceta”, "aparente”, ou seja, era uma cristologia na qual a humanidade de Cristo era apenas aparente, negando a realidade da cruz e contradizendo formalmente o mistério da encarnação.

\section{Inácio, o homem da Regra de fé}

Tendo em vista o perigo que representava para a genuína fé cristã, seja o judeu-cristianismo heterodoxo, que negava a divindade de Jesus, seja o gnosticismo emergente, que negava a humanidade do Salvador, o Bispo de Antioquia desenvolve suas cartas opondo-se a estas compreensões. ${ }^{36}$ Contrapondo estes dois pensamentos que negam, um, a divindade e, outro, a humanidade do Salvador, Inácio conclama à fé em Jesus Cristo Deus e homem verdadeiro e pede aos cristãos que se afastem das doutrinas contrárias à fé.

No corpo joanino já se percebe o combate às tendências separatistas do docetismo e de todas aquelas heresias que o apóstolo condenava, pelo fato de incorrerem no erro de não acreditar na realidade da encarnação (cf. 1 Jo 4,1-6). Inácio, seguindo o esforço do autor joanino, insiste na "perfeita encarnação" ou "verdadeira encarnação" em oposição à "aparente encarnação" dos separatistas. ${ }^{37}$ Acentua a realidade e a facticidade histórica da vida terrena de Jesus; acentuação, esta, realizada em oposição à tendência gnóstica, da qual o docetismo é uma vertente. ${ }^{38}$ Inácio mostra o evento Cristo inserido na

\footnotetext{
${ }^{36}$ Cf. BUENO, D. R. Padres apostólicos, p. 419.

${ }^{37}$ Cf. GRILLMEIER, A. Gesù Il Cristo nella fede della chiesa. 1/1, p. 263.

${ }^{38}$ Bueno apresenta o docetismo como intento teórico para tentar eliminar ou suavizar o escândalo da encarnação e da paixão. Cf. BUENO, D. R. Padres apostólicos, p. 418.
} 
história humana e, por isto, enfatiza que o Jesus sobre qual fala é da família de Davi, que realmente comeu e bebeu entre os homens e foi verdadeiramente crucificado e morto e ressuscitou durante o governo de Pôncio Pilatos. ${ }^{39}$

Em Inácio, a realidade da encarnação é o pressuposto da verdade da salvação, ou seja, negar a encarnação seria dissolver a possibilidade da salvação ${ }^{40}$ Deus apareceu a nós em Jesus: "Deus apareceu em forma humana, para a novidade da vida eterna” ${ }^{41}$ A encarnação é a possibilidade de o ser humano ver a Deus no homem Jesus de Nazaré, que assumiu a condição humana para a nossa salvação, para dar-nos a possibilidade de abraçar a vida eterna. A Cristologia, neste sentido, se encontra a serviço da Soteriologia. Portanto, sua cristologia tem, fundamentalmente, caráter soteriológico-antropológico, uma vez que quer salvaguardar a possibilidade da salvação do ser humano, possibilitada por Cristo ao assumir em Si nossa humanidade. ${ }^{42}$

Contra os cristãos judaizantes, Inácio afirma que “é absurdo falar de Jesus Cristo e viver como judeu” ${ }^{43}$ Ou seja, o bispo reclama aos cristãos a abertura à novidade cristã do Deus que se tornou homem em Jesus Cristo, ou seja, a reconhecer em Jesus, mais do que um profeta, o próprio Deus feito homem. E ainda:

Se, no entanto, alguém vier com interpretações judaicas, não lhe deis ouvido. É melhor ouvir doutrina cristã dos lábios de um homem circuncidado, do que a judaica de um não circuncidado. Se, porém, ambos não falarem de Jesus Cristo, tenho-os em conta de colunas sepulcrais e mesmo de sepulcros, sobre os quais estão escritos apenas nomes de homens. ${ }^{44}$

Inácio, diante daqueles que negam a divindade de Jesus, apresenta o reconhecimento da divindade de Jesus como o princípio do ser cristão, o ponto crucial da passagem do Judaísmo para o

\footnotetext{
${ }^{39}$ Mag 11; Tra 9,1-2; Esm 1-2.

${ }^{40}$ Cf. CARDEnAL, O. G. Cristologia, p. 199.

${ }^{41}$ Efe $19,3$.

${ }^{42}$ Cf. GRILLMEIER, A. Gesù Il Cristo nella fede della chiesa, p. 266.

${ }_{43}$ Mag 10,3.

${ }^{44}$ Fil 6,1.
} 
Cristianismo. ${ }^{45}$ Uma vez que se reconhece Jesus Cristo como Deus, Inácio projeta em Deus, por sua vez, a vida humana de Jesus, inclusive sua paixão: "Permiti que [eu] seja imitador do sofrimento de meu Deus". ${ }^{46}$ Atribui a Deus o que há de humano em Jesus, de modo a falar do sangue e do sofrimento de Deus. ${ }^{47}$ Embora se tenha claro o que se trata da divindade e o que se trata da humanidade, a teologia de Inácio considera a realidade da vida de Jesus contida na pessoa divina do Verbo. Atribuindo à pessoa divina aquilo que Jesus realiza enquanto humano em sua vida terrena.

Tendo a consciência de que não se pode ter, já em Inácio, o pleno sentido do que os concílios posteriores dirão sobre a realidade da verdadeira divindade e humanidade em Jesus Cristo, o que seria um anacronismo, percebe-se, no entanto, que, no bispo de Antioquia, já se têm as pautas das reflexões destes. ${ }^{48}$ Nele, já se evidencia, de algum modo, aquela fé que os concílios posteriores iriam declarar solenemente.

Destarte, vê-se que, com Santo Inácio, já existe uma regra de fé cristã, uma consciência viva de que a fé cristã possui uma normatividade, uma regra existente desde o início na comunidade cristã. Acreditar na verdadeira divindade e verdadeira humanidade de Jesus Cristo é a regula fidei que aparece com clareza nos textos de Santo Inácio, o qual pede aos cristãos para a observarem. ${ }^{49}$ Esta regra de fé é a baliza dos cristãos para que estes continuem fiéis a Cristo:

Exorto-vos, pois - não eu, mas o amor de Jesus Cristo: Servi-vos tão-somente de alimento cristão, abstendo-vos de planta estranha, isto é, de heresia. Misturam Jesus Cristo a si próprios, fazendo passar-se por dignos de fé, como quem ministra droga mortífera

\footnotetext{
${ }^{45}$ Para Inácio, o Judaísmo se opõe nitidamente ao Cristianismo. Por isso, utiliza-se da categoria "Cristianismo" para designar os discípulos de Jesus em oposição ao Judaísmo. E é bem provável que seja o primeiro a utilizar esta categoria. O termo "cristão", de onde provém Cristianismo, tem sua origem em Antioquia (cf. At 11,26). Cf. BUENO, D. R. Padres apostólicos, p. 403.

${ }^{46}$ Rom 6,3.

${ }^{47}$ Cf. SMULDERS, P. Sínteses do Catolicismo primitivo, p.16.

${ }^{48}$ Cf. CARDENAL, O. G. Cristologia, p. 198.

${ }^{49}$ Cf. BUENO, D. R. Padres apostólicos, p. 388.
} 
junto com vinho e mel, bebida que o ignorante toma com gosto, mas gosto mau, pois é para a morte. ${ }^{50}$

Percebe-se, ainda, que há uma preocupação, já no primeiríssimo discurso cristão, seja bíblico, seja patrístico, de se guardar esta regra de fé, evitando-se cair nos erros. Para assegurar esta regra de fé é que Inácio pede aos cristãos que permaneçam junto ao seu bispo, com seu presbitério e seus diáconos. Neste sentido, é possível afirmar que a comunhão hierárquica em Santo Inácio tem a função de assegurar a verdadeira fé apostólica:

Cuidai-vos, pois, de tais pessoas. Fá-lo-eis, se não vos orgulhardes e não vos separardes de Jesus Cristo Deus, nem do bispo nem das prescrições dos Apóstolos. Quem se encontra no interior do santuário é puro; quem se encontra fora do santuário não é puro, isto é, quem pratica alguma coisa sem o bispo, o presbitério e o diácono, este não é puro em sua consciência. ${ }^{51}$

Pode-se observar isto de modo ainda mais claro no texto seguinte:

Sigam todos ao bispo, como Jesus Cristo ao Pai; sigam ao presbitério como aos apóstolos. Acatem os diáconos, como à lei de Deus. Ninguém faça sem o bispo coisa alguma que diga respeito à Igreja. Por legítima seja tida tão-somente a Eucaristia, feita sob a presidência do bispo ou por delegado seu. Onde quer que se apresente o bispo, ali também esteja a comunidade, assim como a presença de Cristo Jesus também nos assegura a presença da Igreja católica. Sem o bispo, não é permitido nem batizar nem celebrar o ágape. Tudo, porém, o que ele aprovar será também agradável a Deus, para que tudo quanto se fizer seja seguro e legítimo. ${ }^{52}$

Não se trata de um infantilismo a respeito daqueles que não são ministros ordenados. Inácio tem claro que o cristão deve ter uma fé adulta, convicções claras a respeito daquilo que professa, ou seja, saber distinguir aquilo que pertence a Deus daquilo que pertence ao

\footnotetext{
50 Tral 6,1-2.

${ }^{51}$ Tral 7,1-2. E ainda: Fil 2,1-2; 3,1-3.

52 Esm 8.
} 
mundo, como se distingue dinheiro verdadeiro do falso. ${ }^{53}$ No entanto, se faz necessário perceber que "para Inácio o problema mais urgente é a conservação da unidade da Igreja." ${ }^{54} \mathrm{E}$, neste sentido, recomenda aos cristãos, em geral, a obedecer ao bispo assim como os presbíteros devem ser unidos a ele. ${ }^{55}$

\section{Ao ser humano a possibilidade de unir-se ao seu Deus}

Inácio é um homem de grande percepção. Ele faz a ponte da realidade humana de Jesus com o passado, o presente e o futuro da humanidade. Ao afirmar a realidade de Cristo assegura a real ligação dos cristãos com Cristo, de forma especial no caminho de cruz, sofrendo com paciência as perseguições e morrendo por causa de sua fé. Deste modo, há no bispo de Antioquia uma graça no martírio: a da ligação íntima com Jesus Cristo, de um verdadeiro discipulado e dá este sentido ao seu martírio: "Preso pelo Nome pela esperança que nos são comuns, confiando chegar até Roma para combater as feras, graças à vossa oração, a fim de ter a felicidade de tornar-me discípulo”. ${ }^{56}$

A entrega ao martírio é a possibilidade de unir-se a Cristo, pelo qual a parusia já se tornou próxima no evento histórico Jesus Cristo. Ele, que aparecerá no fim dos tempos, significa uma nova vida para os fiéis que são os seus membros. Através do Deus que se fez homem, o reino antigo é destruído e substituído pela novidade da vida eterna. Ele possui a convicção de que a vida do cristão é exaltada na unidade sacramental com Cristo e assim recebe um caráter sacramental como participação na paixão, morte e ressurreição de Cristo ${ }^{57}$ Neste sentido, é possível unir-se a Cristo pelo caminho de uma vida terrestre, de uma vida verdadeiramente humana, através da observância dos mandamentos, da união com a Igreja e com os sacramentos e no

\footnotetext{
${ }^{53}$ Mag V 1.

${ }^{54}$ Cf. LAPORTE, J. I Padri della Chiesa, p. 277.

${ }^{55}$ Efe IV.

${ }^{56}$ Efe 1,2. E ainda: Efe 3,1; Rom 2,2; 5,1.

${ }^{57}$ Cf. R. BULTMANN. Ignatius und Paulus. In: GRILLMEIER, A. Gesù Il Cristo nella fede della chiesa, p. 262.
} 
amor aos perseguidores ${ }^{58}$. Neste caminho, Jesus é o "homem novo", o "homem perfeito" pelo qual somos convidados a uma vida nova: "Para padecer junto com Ele, tudo suporto, confortado por Ele, que se tornou perfeito homem". ${ }^{9}$

Em Inácio, formula-se, pela primeira vez, um tema que depois seria decisivo na Cristologia. Trata-se do alcance da graça do evento Cristo, situado em determinado momento histórico, seja para os seus contemporâneos, seja para o futuro, seja para o passado. ${ }^{60}$ Os patriarcas e profetas são vistos também como seguidores de Jesus Cristo, unidos espiritualmente a Ele, ao qual buscavam: "Como, pois, poderemos viver sem Ele, a quem mesmo os Profetas, discípulos pelo Espírito, esperavam como seu Mestre? E foi por isso que Ele, em quem esperavam na justiça, os ressuscitou dos mortos, pela Sua presença”. ${ }^{61}$

E ainda: "Pois os profetas, tão divinos, viveram segundo Jesus Cristo. Por isso mesmo foram perseguidos. Inspiraram-se em Sua graça, a fim de que os incrédulos se convencessem plenamente que há um só Deus, a manifestar-se por Jesus Cristo Seu Filho”.

Nesta cristologia, já se pode perceber o caráter cósmico do evento Jesus Cristo. A salvação de Cristo alcança os seus, mas também os que vivem depois dele e os que viveram antes e, de igual forma, sua graça inspira a vivência de uma vida verdadeiramente cristã até mesmo àqueles que cronologicamente viveram antes de Jesus. Também os que viveram antes de Cristo puderam ter uma vida de intimidade com Ele, tiveram parte no evangelho e na salvação de Cristo. "É Ele a porta para o Pai, pela qual entram Abraão, Isaac e Jacó, os Profetas, os Apóstolos e a Igreja”. ${ }^{62}$ O evento Cristo, neste sentido, embora situado em um determinado momento histórico, ilumina e dá sentido a toda história. É o convite do Pai para que todos, qual que seja o tempo histórico, possam entrar na comunhão com Ele, entrar na vida eterna.

\footnotetext{
${ }^{58}$ Cf. SMULDERS, P. Sínteses do Catolicismo primitivo, p. 17.

${ }^{59}$ Esm 4,2. E também Efe 20,1.

${ }^{60}$ Cf. SMULDERS, P. Sínteses do Catolicismo primitivo, p. 17.

${ }^{61}$ Mag 9,2.

${ }^{62}$ Fil 9,1.
} 


\section{Considerações finais}

Ao tecer, neste trabalho, algumas considerações sobre a cristologia de Inácio de Antioquia, percebe-se a riqueza presente em seus escritos. Embora não seja um discurso sistemático, deles se podem haurir as questões centrais de nossa fé - de forma especial, a verdadeira divindade e verdadeira humanidade de Nosso Senhor Jesus Cristo - verdades as quais o bispo de Antioquia nos convida a crer e que serão declaradas, posteriormente, de forma solene no Concílio de Calcedônia. São, neste sentido, como que as balizas da nossa fé, afirmadas no ardor daquele que fez um encontro decisivo com Cristo a ponto de entregar sua vida até o martírio.

Professar hoje a verdadeira humanidade e divindade de Jesus Cristo, como ensina Inácio, é superar qualquer forma de hipervalorização de uma só das naturezas, que deixaria Jesus Cristo desfigurado de sua real condição. Trata-se de superar os riscos, presentes ainda hoje: seja o de cair no Cristo da fé desprovido de uma vida verdadeiramente humana, seja o de afirmar que Jesus é apenas um homem exemplar, desprovido da divindade. Se, por um lado, há aqueles que desconsideram a humanidade de Jesus, ou seja, que não percebem a profundidade de suas palavras e gestos os quais tiveram grande repercussão a ponto de enfurecer o poder político e religioso de seu tempo, por outro, há aqueles que, buscando dialogar com as outras religiões e filosofias, abandonam o dado da real divindade do Filho e, desta forma, caem em um relativismo religioso e de fé, que, por sua vez, prejudica ao próprio diálogo.

Em Inácio pode-se perceber que a verdade da real divindade e humanidade de Jesus Cristo não é uma mera abstração intelectual, mas percepção do dado da revelação que é, sobretudo, oportunidade de salvação para o ser humano. Estando do lado de Deus e do lado dos homens, ele é a Ponte, o Caminho de comunicação entre o céu e a terra. Por sua vida e morte verdadeiramente humanas, se oferece como o "Deus próximo", que está atento às necessidades do ser humano, sendo solidário para com este e se manifestando, portanto, como Salvador. A salvação em Cristo é, assim, o sentido último das cartas de Inácio. Ele pretende, com as cartas, anunciar esta salvação 
e favorecer que esta seja acolhida por todos os cristãos. Sua reflexão, de caráter soteriológico, é um convite a uma verdadeira acolhida da salvação de Cristo e um chamamento a configurar nossa existência em Cristo, que é nossa verdadeira vida e esperança.

Percebe-se com o estudo dos textos de santo Inácio, a necessidade de "beber do poço" da Patrística. Dela, poder-se-á retirar uma água límpida que sacia e possibilita continuar a caminhada de fé. Por meio dos textos patrísticos, é possível um aggiornamento de nossa fé, pois ela nos remete diretamente à Palavra de Deus, a qual procura aprofundar e refletir por meio de uma linguagem simbólica. O movimento patrístico, que colaborou para a renovação eclesial do Vaticano II, deve ser continuado pelos teólogos, para que, dotados de um conhecimento de causa, possam expressar na linguagem atual o conteúdo da fé bíblica que os Padres em seu tempo se propuseram a apresentar.

\section{Bibliografia}

AGOSTINHO, S. Trindade. São Paulo: Paulus, 1994.

AYÁN, J. Ignazio di Antioquia. In Letteratura Patristica. Cinisello Balsamo (Milano): San Paolo, 2007.

ARNS, P. E. Cartas de Inácio de Antioquia. Petrópolis, RJ: Vozes, 1978.

BUENO, D. R. Padres apostólicos. Edición bilingüe completa. Madri: Biblioteca de autores cristianos, 1974.

CARDENAL, O. G. Cristologia. Madri: Biblioteca de autores cristianos, 2001.

COSTA, P. C. Trindade e cristologia no contexto teológico do II século. Teocomunicação. Porto Alegre, v.33, n. 142, Dez 2003.

DELL'OSSO, C. I Padri apostolici. Traduzione, introduzione e note. Roma: Città Nuova Editrice, 2011.

Documento de Aparecida. Texto Conclusivo da V Conferência Geral do Episcopado Latino-Americano e do Caribe. São Paulo: Edições CNBB, Paulus, Paulinas, 2007.

FORTE, B. Teologia da história: ensaio sobre a revelação, o início e a consumação. São Paulo: Paulus, 1995.

GRILLMEIER, A. Gesù Il Cristo nella fede della chiesa. 1/1. Brescia: Paideia Editrice, 1982.

LAPORTE, J. I Padri della Chiesa. Cinisello Balsamo (Milano): Edizione San Paolo, 2003. 
LIÉBAERT, J. Os Padres da Igreja. Vol I. São Paulo: Ed. Loyola, 2000.

PADOVESE, L. Introdução à teologia patrística. São Paulo: Loyola, 1999.

Padres Apostólicos. Clemente Romano, Inácio de Antioquia, Policarpo de Esmirna, o pastor de Hermas, Carta de Barnabé, Papias. São Paulo: Paulus, 1995.

SESBOÜÉ, B. História dos Dogmas. O Deus da Salvação. Tomo 1. São Paulo: Edições Loyola, 2002.

SIMONETTI, M. Letteratura Cristiana antica. Antologia di testi. Vol. I Dalle origini al terzo secolo: Casale Monterrato(AL): PIEMME, 1996.

SMULDERS, P. Sínteses do Catolicismo primitivo I: A Palavra de Deus na história humana: Inácio, Justino, Irineu In FeINER, J.; LöHRER, M. (ed.). Mysterium Salutis, III/3; Petrópolis, RJ: Vozes, 1985.

http://www.vatican.va/holy_father/benedict_xvi/homilies/2012/documents/ hf_ben-xvi_hom_20121028_conclusione-sinodo_po.html 